\title{
Measuring airway clearance outcomes in bronchiectasis: a review
}

\author{
Lisa J. Franks ${ }^{1,2}$, James R. Walsh ${ }^{1,2,3}$, Kathleen Hall ${ }^{1,4}$ and \\ Norman R. Morris $2,3,5$
}

Affiliations: ${ }^{1}$ Physiotherapy Dept, The Prince Charles Hospital, Chermside, Australia. ${ }^{2}$ School of Allied Health Sciences and Menzies Health Institute, Griffith University, Brisbane, Australia. ${ }^{3}$ Heart Lung Institute, The Prince Charles Hospital, Chermside, Australia. ${ }^{4}$ Physiotherapy, School of Allied Health, Australian Catholic University, Brisbane, Australia. ${ }^{5}$ Allied Health Research Collaborative, Metro North Hospital and Health Service, The Prince Charles Hospital, Chermside, Australia.

Correspondence: Lisa J. Franks, Physiotherapy Dept, The Prince Charles Hospital, Rode Road, Chermside, Queensland 4032, Australia. E-mail: lisa.franksahealth.qld.gov.au

@ERSpublications

For airway clearance research in bronchiectasis, sputum volume, lung function, dyspnoea and healthrelated and cough-related quality of life are currently the most common clinical and patient-reported measures of airway clearance treatment efficacy. https://bit.ly/2KXRdg8

Cite this article as: Franks LJ, Walsh JR, Hall K, et al. Measuring airway clearance outcomes in bronchiectasis: a review Eur Respir Rev 2020; 29: 190161 [https://doi.org/10.1183/16000617.0161-2019].

ABSTRACT While airway clearance techniques (ACTs) are recommended for individuals with bronchiectasis, many trials have demonstrated inconsistent benefits or failed to reach their primary outcome. This review determined the most common clinical and patient-reported outcome measures used to evaluate the efficacy of ACTs in bronchiectasis. A literature search of five databases using relevant keywords and filtering for studies published in English, up until the end of August 2019, was completed. Studies included randomised controlled trials, using crossover or any other trial design, and abstracts. Studies were included where the control was placebo, no intervention, standard care, usual care or an active comparator. Adults with bronchiectasis not related to cystic fibrosis were included. Extracted data comprised study authors, design, duration, intervention, outcome measures and results. The search identified 27 published studies and one abstract. The most common clinical outcome measures were sputum volume $(n=23)$, lung function $(n=17)$ and pulse oximetry $(n=9)$. The most common patientreported outcomes were health-related quality of life (measured with St George's Respiratory Questionnaire, $n=4$ ), cough-related quality of life (measured with Leicester Cough Questionnaire, $n=4$ ) and dyspnoea (measured with Borg/modified Borg scale, $n=8$ ). Sputum volume, lung function, dyspnoea and health- and cough-related quality of life appear to be the most common clinical and patient-reported measures of airway clearance treatment efficacy.

\section{Introduction}

Bronchiectasis is a chronic and progressive lung disease associated with cough, sputum and respiratory infection [1]. It is a highly heterogeneous disease of varied aetiology, coexisting conditions and overlap syndromes [2-4]. Chronic airway infection with pathogenic bacteria is common [5]. Individuals differ in terms of disease severity, exacerbation frequency and prognosis $[6,7]$. Recent years have seen increasing worldwide prevalence of bronchiectasis [8-11], increased economic burden [12-14] and increased interest in clinical trials [15-19]. The objectives of treatment are to improve symptoms and quality of life, prevent respiratory exacerbations and slow disease progression [20, 21]. International guidelines highlight the paucity of evidence-based treatment options available for individuals with bronchiectasis [1, 20].

Provenance: Submitted article, peer reviewed.

Received: 23 Nov 2019 | Accepted after revision: 27 Dec 2019

Copyright $\odot$ ERS 2020. This article is open access and distributed under the terms of the Creative Commons Attribution Non-Commercial Licence 4.0. 
Currently, most therapies are based on low to moderate quality evidence, with many clinical trials failing to reach their primary end-point or outcome, or producing inconsistent findings $[5,19,20,22,23]$.

In contrast, many therapies have demonstrated clinical utility in cystic fibrosis (CF) and COPD [24, 25] with researchers extrapolating these therapies and outcome measures to bronchiectasis [26]. However, the failure of some therapies to show benefits in bronchiectasis, notably recombinant human deoxyribonuclease [27], suggests this approach may be misleading. Despite a lack of high-quality evidence, current international guidelines $[1,20,28,29]$ for the management of bronchiectasis recommend strategies that minimise airway damage by reducing inflammation and infection and improving airway clearance $[28,30]$.

Most individuals with bronchiectasis produce sputum daily and airway clearance is regarded as a mainstay of therapy [20, 31, 32]. Airway clearance techniques (ACTs) are applied by respiratory clinicians to facilitate secretion removal [33-36]. International guidelines $[1,20,28]$ recommend ACTs be personalised to the individual with bronchiectasis to improve outcomes. Although ACTs have been extensively studied in other chronic lung diseases, our understanding of ACT usage remains limited in individuals with bronchiectasis. The purpose of this narrative review is to identify and discuss the most common clinical and patient-reported outcome measures used to evaluate the efficacy of ACTs in bronchiectasis.

\section{Literature search strategy}

A narrative review was conducted on the reporting of airway clearance studies in adults with bronchiectasis. The Cochrane, PubMed, PEDro, EMBASE and MEDLINE databases were searched using the keywords "bronchiectasis", "non-cystic fibrosis bronchiectasis", "airway clearance", "airway clearance techniques", "airway clearance devices", "physiotherapy", "chest physiotherapy" and "positive expiratory pressure devices", and filtered for studies published in English, up until the end of August 2019. The review included randomised controlled trials, using crossover or any other trial design, and abstracts. Only studies examining subjects aged $>18$ years with bronchiectasis not related to CF were included. The interventions involved an airway clearance technique or device. Studies were included in which the control was placebo, no intervention, standard care, usual care or an active comparator. Trials specifically testing pharmacotherapies, diet or exercise were excluded, as the objective of the review was to determine outcomes specifically for airway clearance trials. The principal author extracted the studies and data. Extracted data comprised study authors, design, duration, invention, outcome measures and results. Any issues raised with study inclusion criteria were resolved by discussion with the research team. The search identified 27 published studies and one abstract that were included in this narrative review.

\section{Clinical outcome measures}

\section{Sputum}

The purpose of an ACT is to supplement the body's mucociliary clearance system and facilitate sputum removal [33, 34], with guidelines [1, 20, 25, 28, 29, 37-39] recommending individuals with chronic productive cough or difficulty expectorating sputum be taught ACTs. The rationale by which ACTs improve sputum clearance includes changes in lung volumes, pressures and flows, the use of gravity, and the application of compressive or vibratory forces $[36,40]$.

\section{Sputum volume}

Sputum volume has been assessed in airway clearance studies using different methods including sputum wet weight [41-44], dry weight [42], the volume collected during and/or immediately following an intervention [35, 41-46] or the volume collected in a 24 -h period post-intervention $[35,41,43]$. Studies of airway clearance in bronchiectasis report variations in results on sputum volume. Most studies document an increase in sputum volume with use of ACTs [35, 43, 45, 46] but some report inconsistent findings between different studies depending on when sputum volume was measured [35, 42, 43], while other studies found no benefit on sputum volume with different ACT interventions [41, 42, 44]. These variations may be due to different study populations, variations in ACTs applied and the sputum measurement time-periods. The longer term effect of regular ACTs is relatively unknown, with only one study conducted over 12 months. This study reported that sputum volume during interventions with expiration with an open glottis in the lateral posture (ELTGOL), and $24 \mathrm{~h}$ later, was higher in the ELTGOL group than in the placebo group, both at the beginning and end of the study [35].

While the measurement of sputum volume and weight would appear to be straightforward or simple, there are well-documented limitations with the collection and characterisation of sputum including the compliance required when collecting sputum weight over specific time-periods [30, 47, 48]. Limitations associated with the use of sputum weight include day-to-day variability, within day variability and swallowing of secretions [42]. Variables such as hydration, diet, weather and saliva contamination can also affect sputum weight [47] and the process of obtaining dry sputum weight from wet sputum weight has 
not been standardised [42]. Airway clearance sessions or antibiotic use may increase sputum weight or volume in the short term, but actually reduce sputum weight or volume over the long term as inflammation reduces [47]. Furthermore, none of these studies discussed data on sputum volume variability as an outcome measure or the minimal clinically important difference required for sputum volume. Despite these limitations, 23 out of the 28 reviewed studies used sputum volume as an outcome measure (table 1).

\section{Sputum inflammatory analysis}

Bronchiectasis is characterised by neutrophilic inflammation [67] but only two of the 28 reviewed studies included a sputum cytology measure $[45,52]$ such as neutrophils, lymphocytes, macrophages, eosinophils and total cell count (table 1). Nicolins et al. [45] reported no changes in sputum total cell counts measured after use of high frequency chest wall oscillation (HFCWO) or conventional chest physiotherapy (including positive expiratory pressure (PEP) bottle, PEP mask, ELTGOL and oscillatory PEP) twice daily for 15 days. However, a reduction in neutrophil percentage and an increase in macrophage percentage were observed in the HFCWO group. TAMBASCIO et al. [52] reported no differences in total number of cells, eosinophils, neutrophils, macrophages and lymphocytes between 4 weeks' daily use of an oscillating PEP device, the Flutter, and the comparator group (Flutter generating PEP only, without the inner ball). However, when only the Flutter group was evaluated, there was a decrease in the total number of inflammatory cells. Both studies identify the therapeutic potential of ACTs in improving some sputum inflammatory markers in individuals with stable bronchiectasis.

\section{Sputum microbiology}

The predominance of Pseudomonas aeruginosa in sputum has been shown to increase exacerbations [68, 69] and hospitalisation [69], impair health-related quality of life (HRQoL) [69, 70] and lung function [68], and increase disease severity $[70,71]$ and mortality [69]. The impact of ACTs on both qualitative and quantitative bacteriology has been used to assess response to ACTs, with four of the 28 reviewed studies documenting a measure of sputum microbiology. Using quantitative bacteriology, TAMBASCIO et al. [52] reported Pseudomonas aeruginosa as the most common detected bacteria but found no difference in the total number of colony-forming units pre- and post- 4 weeks' daily use of the Flutter or control. MURRAY et al. [30] also found no differences in sputum bacterial load when using an oscillating PEP device, the Acapella Choice, twice daily for 3 months compared with no ACT in individuals with stable bronchiectasis. Using qualitative bacteriology, MunOz et al. [35] reported Pseudomonas aeruginosa and Haemophilus influenzae to be the two most common pathogens but did not report differences in pathogen number after 12 months of ACT. In a 2-week study by AвDELHALim [46], the authors reported they tested sputum culture and sensitivity; however, the results of these measures were not documented.

\section{Sputum: other}

Several studies included measures of sputum colour [35], purulence [35, 52], adhesiveness [52], mucociliary transport [34,52], viscoelasticity [62] or change in sputum characteristics [62] pre- and post-ACT interventions. While changes were documented the results were inconsistent. Moreover, the methods of reporting these characteristics appear nonstandardised and difficult to replicate, making the application of these results problematic.

\section{Respiratory exacerbations}

Minimising respiratory exacerbations is a key aim in bronchiectasis management [1] and a major topic for pharmacological research in this disease [72]. Until recently there was no consensus-based definition for a respiratory exacerbation in bronchiectasis research [73]. Subsequently, a systematic review of pharmacotherapeutic trial end-points for individuals with bronchiectasis identified many variations in protocol-defined respiratory exacerbations, methods of analyses and durations of follow-up [47]. Unlike pharmacotherapeutic trials, in which the most frequently used end-point was exacerbation frequency, there has only been one study on airway clearance that has used exacerbation frequency and time to first exacerbation as an outcome measure. MunOz et al. [35] conducted the first and longest randomised placebo-controlled trial in airway clearance in bronchiectasis and found twice daily airway clearance (ELTGOL) over 12 months was associated with fewer exacerbations compared with placebo ( $\mathrm{p}=0.042)$. However, the time to first exacerbation was not different between the groups. It is of interest to note that the definition of respiratory exacerbation used in this study does not meet the current consensus definition of a respiratory exacerbation recommended for use in bronchiectasis research. The current definition includes a deterioration in three or more symptoms including cough, sputum (volume, consistency, purulence), breathlessness, exercise tolerance, fatigue, malaise, haemoptysis, and a clinician must determine a change in treatment is required [73]. Now that there is a clearer definition for respiratory exacerbation, it 
TABLE 1 Airway clearance studies in bronchiectasis

\begin{tabular}{|c|c|c|c|c|c|}
\hline $\begin{array}{l}\text { First author } \\
\text { [ref.] }\end{array}$ & Design & Duration & Subjects (n) & Intervention & Outcome measures \\
\hline Munoz [35] & $\begin{array}{l}\text { Randomised } \\
\text { controlled trial }\end{array}$ & 1 year & 44 & $\begin{array}{l}\text { ELTGOL } \\
\text { Placebo } \\
\text { (stretches) }\end{array}$ & $\begin{array}{l}\text { Sputum: volume, purulence, colour, } \\
\quad \text { microbiology } \\
\text { Respiratory function testing: } \mathrm{FEV}_{1} \\
\text { HRQoL: } \mathrm{SGRQ} \\
\text { Cough-related QoL: } \mathrm{LCQ} \\
\text { Dyspnoea: } \mathrm{mMRC} \\
\text { Exercise capacity: } 6 \mathrm{MWT} \\
\text { Exacerbations: frequency, time to first } \\
\text { exacerbation } \\
\text { Systemic inflammation: venous blood } \\
\text { Adherence: self-report diary } \\
\text { Adverse events: } \mathrm{SpO}_{2} \text {, Borg scale for } \\
\text { dyspnoea }\end{array}$ \\
\hline Tsang [41] & $\begin{array}{l}\text { Randomised } \\
\text { controlled trial }\end{array}$ & $<1$ week & $\begin{array}{c}15 \\
\text { (acute exacerbation) }\end{array}$ & $\begin{array}{l}\text { PD + breathing + } \\
\text { cough } \\
\text { Flutter + breathing } \\
\quad+\text { cough } \\
\text { Breathing + cough }\end{array}$ & $\begin{array}{l}\text { Sputum: wet weight } \\
\text { Respiratory function testing: FVC, FEV } \\
\text { PEF } \\
\text { Patient perception: Likert scale (ease and } \\
\text { effectiveness of } A C T \text { ) }\end{array}$ \\
\hline Herala [50] & $\begin{array}{l}\text { Randomised } \\
\text { controlled trial }\end{array}$ & Unclear & 15 & $\begin{array}{l}\text { Thoracic } \\
\text { compression } \\
\text { Bubble PEP }\end{array}$ & $\begin{array}{l}\text { Transcutaneous partial pressure of } \\
\text { carbon dioxide }\end{array}$ \\
\hline DE Souza [51] & $\begin{array}{l}\text { Randomised } \\
\text { crossover }\end{array}$ & 10 days & 40 & $\begin{array}{c}\text { Flutter } \\
\text { Thoracic } \\
\text { compression with } \\
\text { deep breathing } \\
\text { Control (tidal } \\
\text { volume breathing) }\end{array}$ & $\begin{array}{l}\text { Sputum: wet and dry weight, } \\
\text { adhesiveness, purulence } \\
\text { Respiratory function testing: impulse } \\
\text { oscillometry } \\
\text { Dyspnoea: MRC } \\
\text { Patient perception: Likert scales } \\
\text { lacceptability, tolerance, difficulty of } \\
\text { expectorating sputuml } \\
\text { Pulse oximetry: } \mathrm{SpO}_{2} \text {, heart rate }\end{array}$ \\
\hline SILVA [42] & $\begin{array}{l}\text { Randomised } \\
\text { crossover }\end{array}$ & $<2$ weeks & 40 & $\begin{array}{l}\text { Flutter } \\
\text { Lung flute }\end{array}$ & $\begin{array}{l}\text { Sputum: wet and dry weight } \\
\text { Patient perception: Likert scale } \\
\text { (acceptance, tolerability of ACT) }\end{array}$ \\
\hline TAMBASCIO [52] & $\begin{array}{l}\text { Randomised } \\
\text { crossover }\end{array}$ & 10 weeks & 17 & $\begin{array}{c}\text { Flutter } \\
\text { Flutter (PEP only) }\end{array}$ & $\begin{array}{l}\text { Sputum: adhesiveness, purulence, } \\
\text { mucociliary transport, displacement in } \\
\text { simulated cough machine, contact } \\
\text { angle measurement, inflammatory } \\
\text { analysis, microbiology }\end{array}$ \\
\hline
\end{tabular}


TABLE 1 Continued

\begin{tabular}{|c|c|c|c|c|c|}
\hline $\begin{array}{l}\text { First author } \\
\text { [ref.] }\end{array}$ & Design & Duration & Subjects (n) & Intervention & Outcome measures \\
\hline $\begin{array}{l}\text { Herrero-Cortina } \\
\text { [43] }\end{array}$ & $\begin{array}{l}\text { Randomised } \\
\text { crossover }\end{array}$ & 5 weeks & 31 & $\begin{array}{c}\text { AD } \\
\text { ELTGOL } \\
\text { Temporary PEP } \\
\text { (Uniko) }\end{array}$ & $\begin{array}{l}\text { Sputum: wet weight } \\
\text { Respiratory function testing: } \mathrm{FEV}_{1}, \mathrm{FEV}_{1} \% \\
\quad \text { pred, } \mathrm{FVC}, \mathrm{FVC} \% \text { pred, } \mathrm{FEF}_{25-75 \%} \\
\text { Cough-related } \mathrm{QoL}: \mathrm{LCQ} \\
\text { Pulse oximetry: } \mathrm{SpO}_{2} \text {, heart rate } \\
\text { Patient perception: Likert scale } \\
\quad \text { (preference for } \mathrm{ACT} \text { ) } \\
\text { Adverse events: pulse oximetry, heart } \\
\text { rate }\end{array}$ \\
\hline Semwal [44] & $\begin{array}{l}\text { Randomised } \\
\text { crossover }\end{array}$ & 1 day & 30 & $\begin{array}{c}\text { ADA } \\
\text { Acapella }\end{array}$ & $\begin{array}{l}\text { Sputum: volume, wet weight } \\
\text { Respiratory function testing: PEF } \\
\text { Dyspnoea: Modified Borg } \\
\text { Pulse oximetry: } \mathrm{SpO}_{2} \\
\text { Other: Respiratory rate } \\
\text { Patient perception: VAS (comfort of ACT) }\end{array}$ \\
\hline SVEnNingsen [53] & $\begin{array}{l}\text { Randomised } \\
\text { crossover }\end{array}$ & 6 weeks & $\begin{array}{c}29 \text { (15 COPD, } \\
14 \text { bronchiectasis) }\end{array}$ & $\begin{array}{l}\text { Aerobika } \\
\text { Usual care }\end{array}$ & $\begin{array}{l}\text { Respiratory function testing: } \mathrm{FEV}_{1} \% \text { pred, } \\
\text { FVC \% pred, } \mathrm{FEV}_{1} / \mathrm{FVC} \\
\text { HRQoL: SGRQ } \\
\text { Exercise capacity: } 6 \mathrm{MWT} \\
\text { Patient perception: patient evaluation } \\
\quad \text { questionnaire (cough frequency, } \\
\text { dyspnoea, ease in bringing up sputum) }\end{array}$ \\
\hline FIGUEIREDO [33] & $\begin{array}{l}\text { Randomised } \\
\text { crossover }\end{array}$ & 9 days & 8 & $\begin{array}{l}\text { Flutter } \\
\text { Flutter sham }\end{array}$ & $\begin{array}{l}\text { Sputum: volume } \\
\text { Respiratory function testing: Impulse } \\
\text { oscillometry (FOT) }\end{array}$ \\
\hline MURRAY [30] & $\begin{array}{l}\text { Randomised } \\
\text { crossover }\end{array}$ & 7 months & 20 & $\begin{array}{l}\text { Acapella Choice } \\
\text { No chest PT }\end{array}$ & $\begin{array}{l}\text { Sputum: } 24 \text { h sputum volume, } \\
\text { microbiology } \\
\text { Respiratory function testing: } \mathrm{FEV}_{1}, \mathrm{FVC} \text {, } \\
\text { FEF } \mathrm{F}_{25-75 \%, \mathrm{MIP}, \mathrm{MEP}} \\
\text { HRQoL: SGRQ } \\
\text { Cough-related QoL: LCQ } \\
\text { Exercise capacity: incremental shuttle } \\
\text { walk test } \\
\text { Adherence: diary } \\
\text { Adverse events: diary (haemoptysis, } \\
\text { increased use of short-acting } \\
\text { bronchodilator) }\end{array}$ \\
\hline SYED [55] & $\begin{array}{l}\text { Randomised } \\
\text { crossover }\end{array}$ & $<2$ days & 35 & $\begin{array}{c}\text { ACBT with PD } \\
\text { Conventional chest } \\
\text { PT (percussion, } \\
\text { vibrations, } \\
\text { PD, coughing, } \\
\text { breathing) }\end{array}$ & $\begin{array}{l}\text { Sputum: wet weight } \\
\text { Respiratory function testing: FVC, FEV } \\
\text { FEV } \\
\text { Patient perception: VAS (comfort of } A C T \text { ) }\end{array}$ \\
\hline
\end{tabular}


TABLE 1 Continued

\begin{tabular}{|c|c|c|c|c|c|}
\hline $\begin{array}{l}\text { First author } \\
\text { [ref.] }\end{array}$ & Design & Duration & Subjects (n) & Intervention & Outcome measures \\
\hline PatTerson [56] & $\begin{array}{c}\text { Randomised } \\
\text { crossover }\end{array}$ & $10-12$ days & $\begin{array}{c}20 \\
\text { (acute exacerbation) }\end{array}$ & $\begin{array}{l}\text { Acapella DM or } \\
\text { DH with PD } \\
\text { Usual ACT (ACBT, } \\
\text { PEP, huffs, nil) }\end{array}$ & $\begin{array}{l}\text { Sputum: volume/weight } \\
\text { Respiratory function testing } \mathrm{FEV}_{1}, \mathrm{FEV}_{1} \% \\
\text { pred, } \mathrm{FVC}, \mathrm{VC}, \mathrm{PEF} \\
\text { Dyspnoea: Borg scale, 15-count } \\
\text { breathlessness score } \\
\text { Pulse oximetry: } \mathrm{SpO}_{2} \\
\text { Patient symptoms: } \\
\text { Interview-Based Questionnaire } \\
\text { Patient adherence: diary and weekly } \\
\text { phone calls } \\
\text { Patient perception: preference }\end{array}$ \\
\hline Patterson [57] & $\begin{array}{c}\text { Randomised } \\
\text { crossover }\end{array}$ & 2 days & 20 & $\begin{array}{c}\text { Acapella DH and } \\
\text { DM with PD } \\
\text { ACBT (including } \\
\text { percssion, } \\
\text { vibrations and PD) }\end{array}$ & $\begin{array}{l}\text { Sputum: weight } \\
\text { Respiratory function testing: } \mathrm{FEV}_{1}, \mathrm{FEV}_{1} \% \\
\text { pred, } \mathrm{FVC}, \mathrm{FVC} \% \text { pred, PEF, PEF } \% \\
\text { pred } \\
\text { Dyspnoea: } 15 \text { count breathlessness score } \\
\text { Pulse oximetry: } \mathrm{SpO}_{2} \\
\text { Patient perception: questionnaire } \\
\text { (preference) } \\
\text { Other: number of coughs }\end{array}$ \\
\hline THоMPSON [58] & $\begin{array}{c}\text { Randomised } \\
\text { crossover }\end{array}$ & 4 weeks & 17 & $\begin{array}{l}\text { ACBT } \\
\text { Flutter }\end{array}$ & $\begin{array}{l}\text { Sputum: weight } \\
\text { Respiratory function testing: PEF } \\
\text { HRQoL: Chronic Respiratory Disease } \\
\text { Questionnaire } \\
\text { Dyspnoea: Borg scale duration of airway } \\
\text { clearance session } \\
\text { Patient perception: preference }\end{array}$ \\
\hline UzMEZOGLU [61] & $\begin{array}{l}\text { Randomised } \\
\text { comparative }\end{array}$ & 4 weeks & 40 & $\begin{array}{c}\text { Flutter } \\
\text { ACBT with PD }\end{array}$ & $\begin{array}{l}\text { Sputum: change in sputum production } \\
\text { Respiratory function testing: FEV } 1 \% \\
\text { pred, FVC \% pred, } \mathrm{FEV}_{1} / \mathrm{FVC}, \mathrm{PEF} \% \\
\text { predicated } \\
\text { HRQoL: SF-36 } \\
\text { Dyspnoea: Modified Borg, MRC } \\
\text { Patient symptoms: questionnaire }\end{array}$ \\
\hline AbdelHalim [46] & $\begin{array}{l}\text { Randomised } \\
\text { comparative }\end{array}$ & 2 weeks & $\begin{array}{c}30 \\
\text { (acute exacerbation) }\end{array}$ & $\begin{array}{c}\text { ACBT + PD } \\
\text { Conventional } \\
\text { PT (PD } \\
+ \text { diaphragmatic } \\
\text { breathing + } \\
\text { percussion) }\end{array}$ & $\begin{array}{l}\text { Sputum: wet volume, microbiology } \\
\text { Respiratory function testing: } \mathrm{FEV}_{1}, \mathrm{FVC} \text {, } \\
\quad \mathrm{MMEF}, \mathrm{FEV} \mathrm{V}_{1} / \mathrm{FVC} \\
\text { QoL: } \mathrm{LCQ} \\
\text { Dyspnoea: } \mathrm{mMRC} \\
\text { Gas exchange: } \mathrm{PaO}_{2}, \mathrm{PaCO}_{2},{\mathrm{PA}-\mathrm{aO}_{2}} \\
\text { Adverse events: not defined }\end{array}$ \\
\hline
\end{tabular}


TABLE 1 Continued

\begin{tabular}{|c|c|c|c|c|c|}
\hline $\begin{array}{l}\text { First author } \\
\text { [ref.] }\end{array}$ & Design & Duration & Subjects (n) & Intervention & Outcome measures \\
\hline Ramos [62] & $\begin{array}{l}\text { Randomised } \\
\text { comparative }\end{array}$ & 4 days & 22 & $\begin{array}{c}\text { PD + coughing } \\
\text { PD + percussion + } \\
\text { coughing } \\
\text { PD + huff } \\
\text { Control (coughing) }\end{array}$ & $\begin{array}{l}\text { Sputum: wet and dry weight, } \\
\text { viscoelasticity }\end{array}$ \\
\hline
\end{tabular}

\section{EATON [63]}

SVENNINGSEN [64]

\section{D'Abrosca [65]}

GRILLo [66]
Randomised

comparative

Prospective
randomised
comparative

7 days

3 weeks

\begin{abstract}
Retrospective cohort study
\end{abstract}

Minimum

10 days of ACT

14-year data collection period)

Prospective $\quad \sim 2$ weeks Cohort study
37

$$
\begin{gathered}
\text { Flutter } \\
\text { ACBT } \\
\text { ACBT + PD }
\end{gathered}
$$

ACBT + PD
th 
studies in individuals with bronchiectasis have demonstrated lung function is poorly responsive to pharmacotherapy $[17,23,79,80]$. From the 28 reviewed studies on airway clearance, 23 had at least one outcome measure related to lung function. Only one of these 23 studies, a randomised controlled trial by NiCOLINI et al. [45], reported a significant improvement in $\mathrm{FEV}_{1}$ and FVC after using conventional chest physiotherapy or HFCWO twice daily for 15 days, but the authors stated the improvement was unlikely to be of clinical significance.

Other measures of lung function, such as peak expiratory flow, mid-expiratory flow (forced expiratory flow at $25-75 \%$ FVC and maximal mid-expiratory flow), total lung capacity and residual volume, have also been used as outcome measures in 17 out of 28 airway clearance studies but with most reporting no improvements $[30,41,43-46,54,56-59,61,65]$. Therefore, to date, lung function does not appear to be a useful outcome measure for treatment efficacy in bronchiectasis airway clearance studies with durations less than 12 months. It has been suggested that lung function may be more beneficial for monitoring potential adverse treatment effects rather than to assess treatment efficacy [21, 27].

\section{Respiratory muscle strength}

Respiratory muscle strength has also been studied in individuals with bronchiectasis through the measurement of maximal inspiratory and expiratory pressure (MIP and MEP, respectively) [81]. Two of the 28 reviewed studies [30,45] used MIPs and MEPs as outcome measures with conflicting results. Nicolini et al. [45] reported a benefit in MIP and MEP with HFCWO for 15 days compared with control; however, a randomised crossover trial by MURRAY et al. [30] reported no improvement in MIP or MEP with twice daily use of the Acapella Choice compared with no chest physiotherapy over 3 months.

\section{Lung clearance index}

More recently, assessment of peripheral airway function as a measure of disease severity has been explored in CF [82-84] and asthma [85]. The lung clearance index (LCI) is derived from the multiple breath inert gas washout technique and is a measure of airway ventilation heterogeneity [83]. In chronic lung diseases, factors that may contribute to ventilation heterogeneity include sputum retention, airway inflammation and airway wall remodelling, and hence increase washout time [21]. The LCI has been shown to be a valid, reliable and responsive measure in CF [86] and more sensitive to airway damage than spirometry in CF [82]. Some limitations to using LCI include the purchase of expensive equipment, technology required to measure LCI and time and training of staff to administer [82, 87]. Studies investigating the role of LCI in bronchiectasis are very limited. RowAN et al. [88] found LCI a repeatable and sensitive indicator of radiological changes in bronchiectasis [88] and Gonem et al. [89] found the LCI may have potential as a marker of disease severity in bronchiectasis. To date, one study has used the LCI as an outcome measure for airway clearance in bronchiectasis [66]. LCI was repeatable but unresponsive to two single airway clearance interventions; however, the type of ACT was not defined [66]. While the LCI may be a promising outcome measure that examines the important ventilatory heterogeneity, further robust studies examining its efficacy across a range of ACTs and in longer term studies in bronchiectasis are warranted.

\section{Impulse oscillometry/forced oscillatory technique}

Conventional methods of lung function testing provide measurements obtained during specific respiratory manoeuvres of the subject [90]. In contrast, the impulse oscillometry/forced oscillatory technique (FOT) is a noninvasive method of evaluating respiratory mechanics [91] using an interface device that allows its application by means of impulse oscillometry. FOT employs small amplitude pressure oscillations superimposed on normal tidal breathing to describe the resistive and reactive properties of the respiratory system [92] and has the advantage over conventional pulmonary assessment methods in that it is not patient effort dependent [91]. FOT is a reliable measure in the assessment of bronchial responsiveness [93] and has been used to classify disease severity in COPD and asthma [91, 94], and assess lung function in CF [92]. Literature evaluating FOT in adults with bronchiectasis is very limited. GuAN et al. [95] reported that FOT parameters readily discriminated individuals with bronchiectasis from healthy subjects, but were not superior to the diagnostic performance of spirometry. In a more recent study by the same authors, they concluded that FOT and peripheral airway spirometry parameters have similar diagnostic value in reflecting peripheral airway disorders, and correlate with high-resolution computed tomography (HRCT) scores and the bronchiectasis severity index [96]. In terms of using FOT as an outcome measure in airway clearance in bronchiectasis, a small randomised crossover study by FIGUEIREDO et al. [33] found that a single intervention of the Flutter diminished total and peripheral airway resistance in adults with bronchiectasis. Similarly, a recent study by DE SouzA [51] found that the Flutter was effective for secretion removal and decreasing total and peripheral respiratory system resistance, and thoracic compression had comparable positive effects on reducing peripheral resistance. 
Systemic inflammatory analysis

A very limited number of studies have explored the impact of ACTs on haematological measurements in bronchiectasis. Only two of the 28 reviewed studies collected serum inflammatory markers. MunOz et al. [35] included total leukocyte and neutrophil count, C-reactive protein, erythrocyte sedimentation rate and fibrinogen, and Nicolini et al. [45] included C-reactive protein. Munoz et al. [35] reported no differences in systemic inflammatory markers with airway clearance over 12 months, whereas Nicolini et al. [45] reported a reduction in C-reactive protein after using HFCWO twice daily for 15 days compared with conventional chest physiotherapy. The correlation between airway inflammation and systemic inflammation is relatively poor [97] and systemic inflammatory markers may have a minimal role in evaluating responses to ACTs in stable disease. Instead, these markers may have more of a role during acute respiratory exacerbations that are typically associated with a systemic inflammatory response, although further studies are required to determine this [21].

\section{Exercise capacity}

Exercise capacity is an important reflection of respiratory-related function and the 6-min walk test (6MWT) and incremental shuttle walk test (ISWT) are valid and reliable field tests in bronchiectasis [98-100]. Of the 28 reviewed studies, three used the 6MWT $[35,54,65]$ as a measure of exercise capacity and one study used the ISWT [30] in stable bronchiectasis. MURRAY et al. [30] reported an improvement in ISWT distance following 3 months of twice daily use of Acapella Choice. The authors postulated that with greater sputum clearance and cough control, exercise capacity may also improve. Unlike MurRAY et al. [30], MuNOz et al. [35], Svenningsen et al. [53] and Svenningsen et al. [64] did not observe any improvement in the 6MWT. Comparisons between the studies are difficult due to the different exercise tests and study populations. It may be necessary to combine an ACT with a specific exercise-based programme to improve exercise capacity, given that the main objective of ACTs is secretion expectoration $[35,101]$.

\section{Imaging/radiology}

HRCT is the gold standard in diagnosis of bronchiectasis [102], but no studies have used HRCT as an outcome measure in ACT research in bronchiectasis. Only one of the 28 reviewed studies used magnetic resonance imaging (MRI) as an outcome. In this small study by SVENNINGSEN et al. [64], approximately half of the participants had evidence of ventilation improvements on MRI after 3 weeks of daily use of an oscillating PEP device, the Aerobika. Given the very limited evidence available to date, the role of imaging/ radiology as a clinical outcome measure in airway clearance studies is difficult to evaluate and requires further investigation. Limitations such as cost and radiation exposure may also provide reasons for the lack of imaging/radiology outcomes used in airway clearance studies.

\section{Pulse oximetry}

Pulse oximetry is a simple noninvasive approximation of arterial oxygenation and heart rate [103]. Nine of the 28 reviewed studies included an outcome measure of pulse oximetry. No studies documented whether a finger or forehead probe was used. No studies showed a difference in resting oxygen saturation or heart rate pre- or post-ACTs. It is most likely that pulse oximetry has been used as an outcome to assess safety rather than efficacy of ACTs [51].

\section{Gas exchange}

Measures of arterial gas exchange including arterial carbon dioxide tension $\left(P_{\mathrm{aCO}_{2}}\right)$, arterial oxygen tension $\left(P_{\mathrm{aO}_{2}}\right)$ and venous transcutaneous carbon dioxide tension $\left(P_{\mathrm{tcCO}_{2}}\right)$ were used as outcome measures in four of the 28 reviewed studies. A small study by Herala et al. [50] evaluated changes in $P_{\mathrm{tcCO}}$ and reported both thoracic compression and a PEP device (Bubble PEP) temporarily reduced $P_{\mathrm{tcCO}}$. Results varied for other studies with Nicolini et al. [45] finding no differences with ACT on $P_{\mathrm{aO}_{2}}$ and $P_{\mathrm{aCO}}$. ABdelHaLim et al. [46] and D'Abrosca et al. [65], however, reported improvements in $P_{\mathrm{aO}_{2}}$ before and after ACTs. These authors suggested this may be due to ACTs improving alveolar ventilation and optimising ventilation/perfusion matching and therefore improving gas exchange.

\section{Patient-reported outcome measures}

HRQoL

Improving HRQoL is a major goal of management of individuals with bronchiectasis [21]. HRQoL questionnaires in chronic respiratory diseases consist of questions about physical and psychological morbidity and allow clinicians to quantify the effect of the disease on an individual's daily life [21]. Most health-related questionnaires have been minimally validated for use in bronchiectasis and only two, the Bronchiectasis Health Questionnaire (BHQ) and Quality of Life - Bronchiectasis (QOL-B), have been specifically designed for use in this patient population [104, 105]. 
$B H Q$

The BHQ is the most recently developed and validated HRQoL questionnaire for use in bronchiectasis [104]. It is a brief evaluation of 10 items and one single domain including aspects of daily life, sputum and infection [104]. To date, there have been no studies published on bronchiectasis pharmacotherapy or airway clearance research that have used this tool.

\section{QOL-B}

The QOL-B consists of 37 items and eight scales including respiratory symptoms, physical, role, emotional and social functioning, vitality, health perceptions and treatment burden [105]. Although designed and validated for use in bronchiectasis [105], no studies have used it in airway clearance research. The questionnaire has been used in pharmacology clinical trials $[5,22]$ and one qualitative study by DUDGEON et al. [106] investigating patient preference for quality of life tools in bronchiectasis.

\section{St George's Respiratory Questionnaire}

The St George's Respiratory Questionnaire (SGRQ) was developed for use in COPD and is a 50-item self-administered questionnaire assessing the domains of symptoms, activity and impact [107]. It has been validated for use by one study in bronchiectasis [108]. It is the most common HRQoL questionnaire used in airway clearance research in bronchiectasis with four out of the 28 reviewed studies using it. In a small, randomised crossover study by Murray et al. [30], twice daily use of the Acapella Choice compared with no chest physiotherapy over 3 months improved HRQoL (measured using SGRQ). Similarly, a longer term study by MUNOz et al. [35] reported an improvement in SGRQ total score when using ELTGOL compared with placebo. Two short-term studies by SvenningSEN and co-workers [53, 64] reported varying results on SGRQ. In a mixed cohort of COPD and bronchiectasis, 3 weeks of daily Aerobika use improved quality of life (measured using SGRQ) [53]. A study by the same group with a single cohort of individuals with bronchiectasis, however, found no improvements in SGRQ with 3 weeks of daily Aerobika use [64]. Comparing the results of these two studies is not possible because the study by SvENNINGSEN et al. [53] is a published abstract with limited methodological detail and the results from participants with either COPD or bronchiectasis were pooled, which may have impacted study results.

\section{Short Form-36}

The Short Form-36 (SF-36) is a generic 36-item questionnaire with eight subscales including physical function, social function, role limitations for physical problems and emotional problems, mental health, vitality, health perception and health transition [109]. It has been validated for use in individuals with COPD [110], interstitial lung disease [111] and asthma [112] but not for individuals with bronchiectasis. Of the 28 studies reviewed, only one used this questionnaire to evaluate airway clearance in individuals with bronchiectasis. Uzmezoglu et al. [61] reported an improvement in the physical sub-scale of SF-36 score after twice daily use of either the Flutter or active cycle of breathing technique (ACBT) for 4 weeks.

\section{Chronic Respiratory Disease Questionnaire}

The Chronic Respiratory Disease Questionnaire (CRDQ) consists of 20 items and assesses the domains of dyspnoea, fatigue, emotional function and mastery [113]. It was originally developed for use in COPD and has been validated in both COPD [114] and mild to moderate bronchiectasis [115]. The small study by THOMPson et al. [58] used the CRDQ and reported no health impact for individuals with bronchiectasis who completed 4 weeks of daily ACBT or Flutter.

\section{COPD assessment tool}

The COPD assessment tool (CAT) was developed for use in COPD and consists of eight items assessing the global impact of cough, sputum, dyspnoea, and chest tightness on health status [116]. It has been validated for use in individuals with COPD [116] and bronchiectasis [117]. One randomised controlled trial by NiCOLINI et al. [45] reported improvements in CAT scores when using HFCWO and conventional chest physiotherapy compared with controls with bronchiectasis.

\section{Cough-related quality of life}

The Leicester Cough Questionnaire (LCQ) was developed to evaluate quality of life in individuals with chronic cough. It contains 19 items with three domains (physical, psychological and social) and has been validated for use in bronchiectasis [118]. It is one of the most common quality of life measures, with four out of the 28 reviewed studies utilising it. MunOz et al. [35] reported that twice daily ELTGOL over 1 year improved cough impact (measured using LCQ). In a randomised crossover study of 1 week duration by Herrero-CorTina et al. [43], LCQ scores improved with use of autogenic drainage, ELTGOL or temporary PEP, although this improvement was not clinically significant. AbdelHalim et al. [46] reported improvement in the physical domain and total score of the LCQ after using either ACBT or conventional chest physiotherapy twice daily 
for 14 days during a respiratory exacerbation. Furthermore, MURRAY et al. [30] found that with 3 months of twice daily use of Acapella Choice, there was improvement in all domains and total LCQ score.

\section{Dyspnoea}

Medical Research Council scale for dyspnoea

The Medical Research Council scale for dyspnoea (MRC) is a five-point scale (graded from 1 to 5) which establishes functional impairment due to dyspnoea attributable to respiratory disease [119]. It has been used in studies in COPD [120], asthma [121] and idiopathic pulmonary fibrosis [122]. The MRC was used in two out of the 28 reviewed studies.

A study by Uzmezoglu et al. [61] demonstrated reduced MRC scores with daily use of the Flutter, causing a greater improvement in the perception of dyspnoea than when using ACBT. Alternately, a randomised crossover study by De Souza et al. [51] found no reduction in MRC score with use of either the Flutter, thoracic compression or control.

The modified MRC breathlessness scale (mMRC) is similar to the original MRC but uses a five-point scale from 0 to 4 [123]. The three reviewed studies that used the mMRC produced differing results. NicolinI et al. [45] found HFCWO compared with conventional chest physiotherapy produced an improvement in mMRC scores when used twice daily for 15 days. AbDelHalim et al. [46] also reported improvement in mMRC scores before and after the use of both ACBT and twice daily conventional physiotherapy for 14 days during a respiratory exacerbation. A longer duration study by MunOz et al. [35], however, found no differences in mMRC scores after 1 year of daily ELTGOL. The differences in results on dyspnoea are most likely to be attributed to methodological differences between the studies. Furthermore, it is of interest to mention that the Bronchiectasis Severity Index, a valid tool using a combination of clinical, radiological and microbiologic features to predict morbidity and mortality in bronchiectasis, includes the mMRC as one of its components [6].

\section{5-count breathlessness score}

The 15-count breathlessness score is determined by asking the subject to take a large inspiration then count to 15 . The number of breaths that the subject requires to reach a count of 15 is the score. It has been validated for use in children with CF [124] but not in bronchiectasis. Two of the reviewed studies by PAtTeRson and co-workers used this tool as an outcome measure [56, 57]. PATterson et al. [56] reported no differences between pre- and post-treatment dyspnoea for Acapella or usual airway clearance method during a 2 week mild respiratory exacerbation. Another randomised crossover study by PATTERSON et al. [57] studied the Acapella DH, DM or ACBT and reported no differences in dyspnoea.

\section{Borg scale}

The Borg scale is a 15-point subjective scoring system with ratings from 6 to 20 of perceived exertion while performing a particular activity [125]. Four of the 28 reviewed studies used the Borg scale but to assess different factors. MUNOz et al. [35] monitored for any adverse effects of ELTGOL. The other three studies used the Borg scale to monitor perception of dyspnoea pre- and post-ACT interventions. PAtTERSOn et al. [56] found no differences in dyspnoea with the Acapella or usual airway clearance method for 14 days. EATON et al. [63] also found no differences pre- and post-ACTs with the Flutter, ACBT or ACBT with postural drainage over 1 week. A small 4 week randomised crossover study by THOMPSON et al. [58] also found no change in Borg score after individual physiotherapy sessions with either the Flutter or ACBT.

The modified Borg is similar to the original version but is a 12-point scoring system with ratings ranging from 0 to 10 [126]. Four of the 28 reviewed studies used the modified Borg to assess dyspnoea, with varying results. ARIF et al. [49] reported that the combined effect of antibiotic therapy and chest physiotherapy produced an improvement on the modified Borg score of subjects compared with antibiotics or chest physiotherapy alone. Uzmezoglu et al. [61] also reported a reduction in the perception of dyspnoea with daily use of the Flutter and ACBT for 4 weeks compared with study commencement. In contrast, a randomised crossover study by SEMWAL et al. [44] documented no differences between modified Borg dyspnoea scores pre- and post-intervention with a single session of autogenic drainage or Acapella for 20-30 min.

\section{Patient-reported symptoms/perceptions/adherence}

To assist in the prescription of ACTs for individuals with bronchiectasis, it is essential to determine patient perspectives and beliefs about airway clearance and factors affecting adherence. International guidelines [1] recommend that clinicians consider patient preference and adherence when prescribing ACTs, with this recommendation based on expert consensus. Recent data from the European 
Bronchiectasis Data Registry report only half of data registrants performed regular airway clearance [127]. There have only been a limited number of studies investigating symptom burden [106] and adherence [128-130] in individuals with bronchiectasis, all with varying study objectives and methodologies. A study by SPINOU et al. [131] used the LCQ to objectively evaluate cough frequency. The authors found that cough was a common and significant symptom in patients with bronchiectasis, and that sputum, exacerbations and age, but not lung function, were independent predictors of cough frequency [131].

Several studies in bronchiectasis airway clearance research have included an objective measure of patient perception documented by subjects on a Likert scale or questionnaire. These questions explored the perceived effectiveness or ease of use of ACTs [41], acceptance or tolerability of ACTs [42, 57, 63], perceived comfort $[44,55]$ and symptoms such as cough $[57,61]$. The most common question asked is patient preference for an ACT; however, this was only asked in four studies [43, 56, 58, 63]. In some studies $[58,61,63]$, patient-reported perceptions have been asked in addition to HRQoL questionnaires.

Only three of the 28 reviewed studies reported a measure of subject adherence to ACTs, each using a self-report diary card. A randomised crossover study by Murray et al. [30] monitored adherence with the Acapella Choice; however, the authors did not document any details about subject adherence. MunOz et al. [35] measured adherence to ELTGOL and control over 1 year with adherence rates of $80 \%$ and $75 \%$, respectively. PATTERSON et al. [56] evaluated patient adherence during a mild respiratory exacerbation with the Acapella DM/DH with postural drainage and usual airway clearance. The diary card recorded duration of airway clearance sessions, sputum volume produced during airway clearance sessions and dyspnoea. In terms of adherence, the authors reported that subjects completed the diary card daily, but authors did not report definite adherence rates.

\section{Adverse events}

Only four of the 28 reviewed studies commented on any adverse events or side-effects during the studies. MunOz et al. [35] monitored for complications using a diary card and by observing changes in oxygen saturation measured by pulse oximetry and the Borg scale. Herrero-CorTina et al. [43] monitored changes in oxygen saturation measured by pulse oximetry and heart rate. MurRAY et al. [30] monitored adverse events, specifically the presence of haemoptysis or increased use of bronchodilator therapy. ABDELHALIM et al. [46] also monitored adverse events but the authors did not describe their definition of such an event. There were no adverse events reported in any of the four studies.

\section{Discussion}

The aim of this narrative review is to determine and discuss the most common clinical and patient-reported outcome measures used to evaluate the efficacy of ACTs in bronchiectasis. Given that several recent large-scale pharmacological trials have failed to achieve consistently significant results $[5,19,22]$, a re-evaluation of the outcome measures used in bronchiectasis is timely. International guidelines over the past decade have also emphasised the need for high-quality evidence to support ACTs in bronchiectasis [1, 20, 29, 132]. A recent editorial has issued a "call for action" for increased awareness and research into ACTs in bronchiectasis and the need for establishing clinically important outcomes [133]. The European Respiratory Society guidelines also confirmed the nine most important Patient/problem, Intervention, Comparison, Outcome (PICO) topics agreed between clinicians and patients, with respiratory physiotherapy considered one of the most important [20]. Therefore, it is essential to reach consensus for the most clinical and patient-reported outcome measures for airway clearance to guide development of future studies.

Our review has demonstrated that there is indeed a large range of outcome measures; however, some are clearly used in more trials than others. The most common clinical outcomes used include measures of sputum volume, lung function and pulse oximetry. Even though these are the most frequently used outcomes in trials to date, they are not without their limitations. As the objective of ACTs is to improve sputum clearance, it is not surprising that a large proportion of studies used sputum volume as an outcome. Although there are limitations to using sputum volumes, the perception of the individual with bronchiectasis about sputum is very important to assess. The optimal method for obtaining sputum volume requires further investigation to determine what is most reliable and repeatable. Studies are also required to identify sputum cytology measures and evaluate microbiology during studies of airway clearance, particularly during respiratory exacerbations. What is interesting is that many studies used lung function, namely spirometry, to assess efficacy of ACTs despite the sensitivity of spirometry being a questionable measure of short- to medium-term treatment efficacy in airway clearance studies [35, 46]. Further studies are needed to assess the impact of lung function in relation to patient health status and the relevance of different measurements of lung function in assessing response to ACTs. Adequately powered studies that include clinical outcome measures for small airway function, such as FOT or LCI, may be more clinically useful or sensitive to assessing treatment response. 
The most common patient-reported outcomes included HRQoL, cough-related quality of life and dyspnoea. HRQoL can be significantly impaired in individuals with bronchiectasis $[105,106,134]$ and, therefore, it is important to assess this patient-reported outcome especially due to the long-term treatment burden associated with ACTs. There are also differences in approaches to measuring quality of life in airway clearance studies and limited information has been published about minimal clinically important differences in these measures. It is interesting to observe that no airway clearance studies included the QOL-B, despite it being designed for and validated in bronchiectasis. Furthermore, a qualitative study by DUdGeOn et al. [106] compared four different quality of life measures in bronchiectasis and reported that QOL-B was the preferred measure compared with the CAT, LCQ and SGRQ. The QOL-B and BHQ are relatively new outcome measures and may be the reason why they are yet to be used in airway clearance research.

The LCQ was the only measure used to investigate cough-related quality of life. The most common measure of dyspnoea was the Borg or modified Borg scale, but there is some confusion in the interpretation of the results of these studies as the authors did not describe the way patients assessed dyspnoea. It is not clear which anchor points or terminology was used, or whether these scales scored dyspnoea exclusively or rate of perceived exertion. It is therefore important that future studies use standardised versions of scales that are specifically validated to quantify dyspnoea intensity. It is reasonable that cough-related quality of life and dyspnoea were assessed in studies as they are some of the main symptoms of bronchiectasis. This is also supported by HaLl et al. [135] who evaluated the impact of a specialist respiratory physiotherapy clinic on health and cough-related quality of life. Patients attended two clinic visits 4 to 6 weeks apart for individualised physiotherapy sessions (involving ACTs, exercise and use of adjunctive inhalation therapies) and reported improvements in the CAT and LCQ scores.

Other important factors to consider are patient preference and adherence to ACTs. As international guidelines recommend that clinicians consider these factors when prescribing ACTs [1], the fact few studies included these as outcomes is concerning. Future studies should include these outcomes, as well as potential recommendations regarding the minimum criteria for adherence to airway clearance and offer strategies to help maximise adherence.

Much like the literature examining therapeutic options in this population, the current evidence base for ACTs in bronchiectasis remains ambiguous due to variations in study aims, methodologies and outcome measures. Research challenges include the personalisation of ACTs, study blinding and placebo effects. Study designs including active comparators, clusters based on endotypes or phenotypes, or stepped-wedge implementation trials are alternative approaches that require consideration for future studies [133]. Adding to the confusion, there is currently no validated respiratory exacerbation prediction tool and there have been varying definitions of respiratory exacerbations in airway clearance studies $[46,59]$. Factors such as disease heterogeneity, varying disease aetiology, ranging disease severity, coexisting conditions and overlap syndromes have made comparison of studies difficult. The methodological quality of the literature is variable with differences in risk of study bias, time frames and characterisation or definition of outcome measures. Most of the studies reviewed are crossover trials $(n=16)$, with one placebo-controlled trial, and many randomised studies $(n=26)$. Perhaps the most important and potentially significant limitation is that nearly all studies are short term. As bronchiectasis is a chronic and progressive disease, it is pivotal that studies investigating the efficacy of regular ACTs be conducted in long-term (>12 month) studies. The longer term trials by MUNOZ et al. [35] and Murray et al. [30] provide important results in this way regarding the effect of ACTs over 12 and 7 months, respectively.

HRQoL measures specifically designed and validated for individuals with bronchiectasis, such as the BHQ and QOL-B, should be examined further in studies along with cough-related quality of life and patient-reported symptoms. Treatment decisions and airway clearance prescription by clinicians should consider the potential beneficial effects of the ACT, supporting evidence for the ACT, current treatment burden and risk for adverse events [20]. It is essential that an integrated and personalised approach be applied when prescribing ACTs that includes patient preference, sputum quality, exacerbation history, quality of life, disease severity and underlying aetiology, as these factors may effect long-term outcomes [20]. Given the current state of knowledge, further studies are needed to investigate the optimum method of ACT, duration and frequency. Assessment of clinical and patient-reported outcome measures over the long term in varying severities of bronchiectasis are required, as well as evaluating the effects of ACTs in individuals undergoing a respiratory exacerbation.

\section{Summary}

This review has identified and discussed the most common clinical and patient-reported outcome measures used to assess efficacy of ACTs in bronchiectasis. While there is large heterogeneity in the studies published to date, the most common clinical outcome measures are sputum volume, lung function 
and pulse oximetry. The most common patient-reported outcome measures are health and cough-related quality of life and dyspnoea. There is an urgent need for guidance to standardise and implement the most important clinical and patient-reported outcome measures in long-term studies to increase the likelihood of demonstrating significant benefits and to guide personalised prescription of ACTs in bronchiectasis.

Conflict of interest: None declared.

\section{References}

1 Hill A, Sullivan A, Chalmers J, et al. British Thoracic Society Guideline for bronchiectasis in adults. Thorax 2019; 74: Suppl. 1, 1-69.

2 Contarini M, Finch S, Chalmers J. Bronchiectasis: a case-based approach to investigation and management. Eur Respir Rev 2018; 27: 180016.

$3 \mathrm{Du} \mathrm{Q}$, Jin J, Liu X, et al. Bronchiectasis as a comorbidity of chronic obstructive pulmonary disease: a systematic review and meta-analysis. PLoS One 2016; 11: e0150532.

4 Polverino E, Dimakou K, Hurst J, et al. The overlap between bronchiectasis and chronic airways diseases: state of the art and future directions. Eur Respir J 2018; 52: 1800328.

5 Barker A, O'Donnell A, Flume P, et al. Aztreonam for inhalation solution in patients with non-cystic fibrosis bronchiectasis (AIR-BX1 and AIR-BX2): two randomised double-blind, placebo-controlled phase 3 trials. Lancet Respir Med 2014; 2: 738-749.

6 Chalmers J, Goeminne P, Sliberti S, et al. The bronchiectasis severity index. An international derivation and validation study. Am J Respir Crit Care Med 2014; 189: 576-585.

7 Metersky M, Chalmers J. Bronchiectasis insanity: doing the same thing over and over again and expecting different results? F1000Res 2019; 8: 1-7.

8 Quint J, Millett E, Joshi M, et al. Changes in the incidence, prevalence and mortality of bronchiectasis in the UK from 2004 to 2013: a population-based cohort study. Eur Respir J 2016; 47: 186-193.

9 Chang A, Frimwood K, Maguire G, et al. Management of bronchiectasis and chronic suppurative lung disease in Indigenous children and adults from rural and remote Australian communities. Med J Aust 2008; 189: 386-393.

10 Ringshausen F, de Roux A, Diel R, et al. Bronchiectasis in Germany: a population-based estimation of disease prevalence. Eur Respir J 2015; 46: 1805-1807.

11 Quint J, Smith M. Paediatric and adult bronchiectasis: diagnosis, disease burden and prognosis. Respirology 2019; 24: 413-422.

12 Diel R, Chalmers J, Rabe K, et al. Economic burden of bronchiectasis in Germany. Eur Respir J 2019; 53: 1802033.

13 Weycker D, Edelsberg J, Oster G, et al. Prevalence and economic burden of bronchiectasis. Clin Pulm Med 2005; 12: 205-209.

14 Goeminne PC, Hernandez F, Diel R, et al. The economic burden of bronchiectasis - known and unknown: a systematic review. BMC Pulm Med 2019; 19: 54.

15 Altenburg J, de Graaff C, Stienstra Y, et al. Effect of azithromycin maintenance treatment of infectious exacerbations among patients with non-cystic fibrosis bronchiectasis: the BAT randomised controlled trial. JAMA 2014; 309: 1251-1259.

16 Wong C, Jayaram L, Karalus N, et al. Azithromycin for prevention of exacerbations in non-cystic fibrosis bronchiectasis (EMBRACE): a randomised, double-blind, placebo-controlled trial. Lancet 2012; 380: 660-667.

17 Serisier D, Martin M, McGuckin M, et al. Effect of long-term, low-dose erythromycin in pulmonary exacerbations among patients with non-cystic fibrosis bronchiectasis. JAMA 2013; 309: 1260-1267.

18 Stockley R, DeSoyza A, Gunawardena K, et al. Phase II study of a neutrophil elastase inhibitor (AZD9668) in patients with bronchiectasis. Respir Med 2013; 107: 524-533.

19 Aksamit T, DeSoyza A, Bandel T, et al. RESPIRE 2: a phase III placebo-controlled randomised trial of ciprofloxacin dry powder for inhalation in non-cystic fibrosis bronchiectasis. Eur Respir J 2018; 51: 1702053.

20 Polverino E, Goeminne P, McDonnell M, et al. European Respiratory Society guidelines for the management of adult bronchiectasis. Eur Respir J 2017; 50: 1700629.

21 Smith M, Hill A. Evaluating success of therapy for bronchiectasis. What end points to use? Clin Chest Med 2012; 33: 329-349.

22 De Soyza A, Aksamit T, Bandel T, et al. RESPIRE 1: a phase III placebo-controlled randomised trial of ciprofloxacin dry powder for inhalation in non-cystic fibrosis bronchiectasis. Eur Respir J 2018; 51: 1702052.

23 Bilton D, Tino G, Barker A, et al. Inhaled mannitol for non-cystic fibrosis bronchiectasis: a randomised, controlled trial. Thorax 2014; 69: 1073-1079.

24 National Institute for Health and Clinical Excellence (NICE). Cystic fibrosis: diagnosis and management. www. nice.org.uk/guidance/ng78 Date last updated: October 2017; date last accessed 14 July 2019.

25 Yang I, Dabscheck E, George J, et al. The COPD-X Plan: Australian and New Zealand guidelines for the management of chronic obstructive pulmonary disease. Med J Aust 2017; 207: 436-442.

26 Athanazio R, Rached S, Rohde C, et al. Should the bronchiectasis treatment given to cystic fibrosis patients be extrapolated to those with bronchiectasis from other causes? J Brasil Pneum 2010; 36: 425-431.

27 O'Donnell A, Barker A, Ilowite J, et al. Treatment of idiopathic bronchiectasis with aerosolized recombinant human DNase I. rhDNase Study Group. Chest 1998; 113: 1329-1334.

28 Chang A, Bell S, Torzillo P, et al. Chronic suppurative lung disease and bronchiectasis in children and adults in Australia and New Zealand: Thoracic Society of Australia and New Zealand guidelines. Med J Aust 2015; 202: 130. Pasteur M, Bilton D, Hill A. British Thoracic Society guideline for non-CF bronchiectasis. Thorax 2010; 65: i1-i58.

30 Murray M, Pentland J, Hill A. A randomised crossover trial of chest physiotherapy in non-cystic fibrosis bronchiectasis. Eur Respir J 2009; 34: 1086-1092.

31 Visser S, Bye P, Morgan L. Management of bronchiectasis in adults. Med J Aus 2018; 1: 12-17.

32 Chalmers J, Aliberti S, Blasi F. State of the art review: management of bronchiectasis in adults. Eur Respir J 2015; 45: 1446-1462. 
33 Figueiredo P, Zin W, Guimarães F. Flutter valve improves respiratory mechanics and sputum production in patients with bronchiectasis. Physiother Res Int 2012; 17: 12-20.

34 Tambascio J, de Souza L, Lisboa R, et al. The influence of Flutter ${ }^{\otimes}$ VRP1 components on mucus transport of patients with bronchiectasis. Respir Med 2011; 105: 1316-1321.

35 Munoz G, de Gracia J, Buxi M, et al. Long-term benefits of airway clearance in bronchiectasis: a randomised placebo-controlled trial. Eur Respir J 2018; 51: 1701926.

36 Lee A, Burge A, Holland A. Airway clearance techniques for bronchiectasis. Cochrane Database Syst Rev 2015; 23: CD008351.

37 Chang A, Bell S, Byrnes C, et al. Chronic suppurative lung disease and bronchiectasis in children and adults in Australia and New Zealand. Med J Aust 2010; 193: 356-365.

38 Button B, Wilson C, Dentice R, et al. Physiotherapy for cystic fibrosis in Australia and New Zealand: a clinical practice guideline. Respirol 2016; 21: 656-667.

39 National Institute for Health and Care Excellence (NICE). Chronic obstructive pulmonary disease in over 16s: diagnosis and management. www.nice.org.uk/guidance/ng115 Date last updated: July 2019; date last accessed: 14 June 2019.

40 Button BM, Button B. Structure and function of the mucus clearance system of the lung. Cold Spring Harb Perspect Med 2013; 3: a009720.

41 Tsang S, Jones A. Postural drainage or Flutter device in conjunction with breathing and coughing compared to breathing and coughing alone in improving secretion removal and lung function in patients with acute exacerbation of bronchiectasis: a pilot study. Hong Kong Physiother J 2003; 21: 29-36.

42 Silva Y, Greer T, Morgan L, et al. A comparison of two respiratory devices for sputum clearance in adults with non-cystic fibrosis bronchiectasis. Respir Care 2017; 62: 1291-1297.

43 Herrero-Cortina B, Vilaró J, Martí D, et al. Short-term effects of three slow expiratory airway clearance techniques in patients with bronchiectasis: a randomised crossover trial. Physiother 2016; 102: 357-364.

44 Semwal S, Mitra S, Singh S. Autogenic drainage versus acapella for airway clearance in bronchiectasis: randomised crossover trial. Int J Health Sci Res 2015; 5: 323-327.

45 Nicolini A, Dardini F, Landucci N, et al. Effectiveness of treatment with high-frequency chest wall oscillation in patients with bronchiectasis. BMC Pulm Med 2013; 13: 1-8.

46 AbdelHalim HA, AboElNaga HH, Fathy KA. Comparison between active cycles of breathing with postural drainage versus conventional chest physiotherapy in subjects with bronchiectasis. Egypt J Chest Dis Tuberc 2016; 65: 157-165.

47 Crichton M, Aliberti S, Chalmers J. A systematic review of pharmacotherapeutic end-points for bronchiectasis in adults. Eur Respir Rev 2019; 28: 180108

48 Garcia-Vazquez E, Marcos M, Mensa J. Assessment of the usefulness of sputum culture for diagnosis of community-acquired pneumonia using the PORT predictive scoring system. Arch Intern Med 2004; 164: 1807-1811.

49 Arif M, Bashir M, Noor R. Effectiveness of chest physiotherapy in the management of bronchiectasis. Annals KEMU 2014; 20: 205-219.

50 Herala M, Gislason T. Chest physiotherapy: evaluation by transcutaneous blood gas monitoring. Chest 1988; 93: $800-802$.

51 de Souza L, Dos Santos D, Celso H, et al. Acute effects of oscillatory PEP and thoracic compression on secretion removal and impedance of the respiratory system in non-cystic fibrosis bronchiectasis. Respir Care 2019; 64: $818-827$.

52 Tambascio J, de Souza H, Martinez R, et al. Effects of an airway clearance device on inflammation, bacteriology, and mucus transport in bronchiectasis. Respir Care 2017; 62: 1067-1074.

53 Svenningsen S, Paulin G, Wheatley A, et al. Oscillating positive expiratory pressure (oPEP) therapy in chronic obstructive pulmonary disease and bronchiectasis. Eur Respir J 2014; 44: Suppl. 58, P3679.

54 Guimarães F, Moço V, Menezes S, et al. Effects of ELTGOL and Flutter VRP1 on the dynamic and static pulmonary volumes and on the secretion clearance of patients with bronchiectasis. Braz J Phys Ther 2012; 16: 108-113.

55 Syed N, Maiya A, Kumar T. Active cycles of breathing technique (ACBT) versus conventional chest physical therapy on airway clearance in bronchiectasis: a crossover trial. Adv Physiother 2009; 11: 193-198.

56 Patterson J, Hewitt O, Kent L, et al. Acapella versus usual airway clearance during acute exacerbation in bronchiectasis: a randomized crossover trial. Chron Respir Dis 2007; 4: 67-74.

57 Patterson J, Bradley J, Hewitt O, et al. Airway clearance in bronchiectasis: a randomized crossover trial of active cycle of breathing techniques versus Acapella. Respiration 2005; 72: 239-242.

58 Thompson C, Harrison S, Ashley J, et al. Randomised crossover study of the Flutter device and the active cycle of breathing technique in non-cystic fibrosis bronchiectasis. Thorax 2002; 57: 446-448.

59 Antunes L, Carvalho S, Borges F, et al. A study of the conventional chest physiotherapy versus Flutter VRP1 in the treatment of patients carrying bronchiectasis. Salusvita 2001; 20: 23-33.

60 Sutton $\mathrm{P}$, Gemmell $\mathrm{H}$, Innes $\mathrm{N}$, et al. Use of nebulised saline and nebulised terbutaline as an adjunct to chest physiotherapy. Thorax 1988; 43: 57-60.

61 Uzmezoglu B, Altiay G, Ozdemir L, et al. The efficacy of Flutter and active cycle of breathing technique in patients with bronchiectasis: a prospective, randomised comparative study. Turk Thorac J 2018; 19: 103-109.

62 Ramos E, Ramos D, Moreira G, et al. Viscoelastic properties of bronchial mucus after respiratory physiotherapy in subjects with bronchiectasis. Respir Care 2015; 60: 724-730.

63 Eaton T, Young P, Zeng I, et al. A randomized evaluation of the acute efficacy, acceptability and tolerability of flutter and active cycle of breathing with and without postural drainage in non-cystic fibrosis bronchiectasis. Chron Respir Dis 2007; 4: 23-30.

64 Svenningsen S, Guo F, McCormack D, et al. Noncystic fibrosis bronchiectasis: regional abnormalities and response to airway clearance therapy using pulmonary functional magnetic resonance imaging. Acad Radiol 2017; 24: 4-12.

65 D'Abrosca F, Garabelli B, Savio G, et al. Comparing airways clearance techniques in chronic obstructive pulmonary disease and bronchiectasis: positive expiratory pressure or temporary positive expiratory pressure? A retrospective study. Braz J Phys Ther 2017; 21: 15-23. 
Grillo L, Irving S, Hansell D, et al. The reproducibility and responsiveness of the lung clearance index in bronchiectasis. Eur Respir J 2015; 46: 1645-1653.

67 Bedi P, Davidson D, McHugh B, et al. Blood neutrophils are reprogrammed in bronchiectasis. Am J Respir Crit Care Med 2018; 198: 880-890.

68 Rogers G, Zain N, Bruce $\mathrm{K}$, et al. A novel microbiota stratification system predicts future exacerbations in bronchiectasis. Annals Am Thor Soc 2013; 11: 496-503.

69 Finch S, McDonnell M, Abo-Leyah H, et al. A comprehensive analysis of the impact of Pseudomonas aeruginosa colonization on prognosis in adult bronchiectasis. Ann Am Thorac Soc 2015; 12: 1602-1611.

70 Aliberti S, Lonni S, Dore S, et al. Clinical phenotypes in adult patients with bronchiectasis. Eur Respir J 2016; 47: 1113-1122.

71 Dicker A, Fong C, Crichton M, et al. Altered lung microbiota profiles are associated with disease severity, exacerbation frequency and neutrophilic inflammation in bronchiectasis. Am J Respir Crit Care Med 2016; 193: A2879.

72 Dabrh A, Hill A, Dobler C, et al. Prevention of exacerbations in patients with stable non-cystic fibrosis bronchiectasis: a systematic review and meta-analysis of pharmacological and non-pharmacological therapies. BMJ Evid Based Med 2018; 23: 96-103.

73 Hill A, Haworth C, Aliberti S, et al. Pulmonary exacerbation in adults with bronchiectasis: a consensus definition for clinical research. Eur Respir J 2017; 49: 1700051.

74 Wainwright C, Stuart E, Ramseyd B, et al. Lumacaftor-ivacaftor in patients with cystic fibrosis homozygous for Phe508del CFTR. N Engl J Med 2015; 373: 220-231.

75 Hakim A, Khan Y, Esteban I, et al. Low-dose budesonide/formoterol counteracts airway inflammation and improves lung function in chronic obstructive pulmonary disease. Am J Respir Crit Care Med 2019; 199: $662-664$.

76 Culver B, Graham B, Coates A, et al. Recommendations for a standardised pulmonary function report. An official American Thoracic Society technical statement. Am J Respir Crit Care Med 2017; 196: 1463-1472.

77 Brusasco V, Crapo R, Viegi G. Coming together: the ATS/ERS consensus on clinical pulmonary function testing. Eur Respir J 2005; 26: 1-2.

78 Thoracic Society of Australia and New Zealand. Standards for the delivery of spirometry for coal mine workers. Sydney, Thoracic Society of Australia and New Zealand, 2017; pp. 1-17.

79 Herrero-Cortina B, Alcaraz V, Vilaro J, et al. Impact of hypertonic saline solutions on sputum expectoration and their safety profile in patients with bronchiectasis: a randomised crossover trial. J Aeros Pulm Drug Deliv 2018; 31: 281-289.

80 Serisier J, Bilton D, DeSoyza A, et al. Inhaled, dual release liposomal ciprofloxacin in non-cystic fibrosis bronchiectasis (ORBIT-2): a randomised, double-blind, placebo-controlled trial. Thorax 2013; 68: 812-817.

81 Moran F, Piper A, Elborn J, et al. Respiratory muscle pressures in non-CF bronchiectasis: repeatability and reliability. Chron Respir Dis 2010; 7: 165-171.

82 Horsley A, Gustafsson P, Macleod K, et al. Lung clearance index is a sensitive, repeatable and practical measure of airways disease in adults with cystic fibrosis. Thorax 2008; 63: 135-140.

83 Verbanck S, King G, Zhou W, et al. The quantitative link of lung clearance index to bronchial segments affected by bronchiectasis. Thorax 2018; 73: 82-84.

84 Davies J, Sheridan H, Lee P, et al. Effect of ivacaftor on lung function in subjects with CF who have the G551D-CFTR mutation and mild lung disease: a comparison of lung clearance index (LCI) vs. spirometry. J Cyst Fibros 2012; 11: 15 .

85 Gustafsson P. Peripheral airway involvement in CF and asthma compared by inert gas washout. Pediatr Pulmonol 2007; 42: 168-176.

86 Kent L, Reix P, Innes J, et al. Lung clearance index: evidence for use in clinical trials in cystic fibrosis. J Cyst Fibros 2014; 13: 123-138.

87 Horsley A. Lung clearance index in the assessment of airways disease. Respir Med 2009; 103: $793-799$.

88 Rowan S, Bradley J, Bradbury I, et al. Lung clearance index is a repeatable and sensitive indicator of radiological changes in bronchiectasis. Am J Respir Crit Care Med 2014; 189: 586-592.

89 Gonem S, Scadding A, Soares M, et al. Lung clearance index in adults with non-cystic fibrosis bronchiectasis. Respir Res 2014; 15: 59 .

90 Smith H, Reinhold P, Goldman M. Forced oscillation technique and impulse oscillometry. In: Gosselink R, Stam H, eds. Lung Function Testing (ERS Monograph). Sheffield, European Respiratory Monograph 2005; 31: 72-105.

91 Oostveen E, MacLeod D, Lorino $\mathrm{H}$, et al. The forced oscillation technique in clinical practice: methodology, recommendations and future developments. Eur Respir J 2003; 22: 1026-1041.

92 Lima A, Faria A, Lopes A, et al. Forced oscillations and respiratory system modeling in adults with cystic fibrosis. Biomed Engin Online 2015; 14: 11.

93 Alblooshi A, Alkalbani A, Albadi G, et al. Is forced oscillation technique the next respiratory function test of choice in childhood asthma? World J Methodol 2017; 7: 129-138.

94 Kim C, Kim J, Park J, et al. Clinical applications of forced oscillation techniques (FOT) in patients with bronchial asthma. Korean J Intern Med 2001; 16: 80-86.

95 Guan W-J, Gao Y-H, Gang L, et al. Impulse oscillometry in adults with bronchiectasis. Ann Am Thorac Soc 2015; 12: 657-665.

96 Guan W-J, Yuan J-J, Gao Y-H, et al. Impulse oscillometry and spirometry small airway parameters in bronchiectasis. Respir Care 2016; 61: 1513-1522.

97 Nunez B, Sauleda J, Garcia-Aymerich J, et al. Lack of correlation between pulmonary and systemic inflammation markers in patients with chronic obstructive pulmonary disease: a simultaneous, two-compartmental analysis. Arch Bronconeumol 2016; 52: 361-367.

98 de Camargo A, Amaral T, Rached S, et al. Incremental shuttle walking test: a reproducible and valid test to evaluate exercise tolerance in adults with noncystic fibrosis bronchiectasis. Arch Phys Med Rahabil 2014; 95: 892-899.

99 Cartlidge M, Smith M, Bedi P, et al. Validation of the incremental shuttle walk test as a clinical end point in bronchiectasis. Chest 2018; 156: 1321-1329. 
Lee A, Cecins N, Holland A. Field walking tests are reliable and responsive to exercise training in people with non-cystic fibrosis bronchiectasis. J Cardiopulm Rehabil Prev 2015; 35: 439-445.

101 Mandal P, Sidhu M, Kope L, et al. A pilot study of pulmonary rehabilitation and chest physiotherapy versus chest physiotherapy alone in bronchiectasis. Respir Med 2012; 106: 1647-1654.

102 Basaran A, Basaran A, Maslak I, et al. Evaluation of noncystic fibrosis bronchiectasis using clinical and radiological scorings in children. Turk Thorac J 2018; 19: 159-164.

103 Pretto J, Roebuck T, Beckert L, et al. Clinical use of pulse oximetry: official guidelines from the Thoracic Society of Australia and New Zealand. Respirology 2014; 19: 38-46.

104 Spinou A, Siegert R, Guan W, et al. The development and validation of the Bronchiectasis Health Questionnaire. Eur Respir J 2017; 49: 1601532.

105 Quittner A, O’Donnell A, Salathe M, et al. Quality of Life Questionnaire-Bronchiectasis: final psychometric analyses and determination of minimal important difference scores. Thorax 2015; 70: 12-20.

106 Dudgeon E, Crichton M, Chalmers J. “The missing ingredient": the patient perspective of health related quality of life in bronchiectasis: a qualitative study. BMC Pulm Med 2018; $18: 81$.

107 Jones P, Quirk F, Baveystock C, et al. A self-complete measure of health status for chronic airflow limitation. Am Rev Respir Dis 1992; 145: 1321-1327.

108 Wilson C, Jones O, O'Leary C, et al. Validation of the St George's Respiratory Questionnaire in bronchiectasis. Am J Respir Crit Care Med 1996; 156: 536-541.

109 Ware J, Sherbourne C. The MOS 36-item short-form health survey. Med Care 1992; 30: 473-483.

110 Mahler D, Mackowiak J. Evaluation of the short-form 36-item questionnaire to measure health-related quality of life in patients with COPD. Chest 1995; 107: 1585-1589.

111 Chang J, Curtis J, Patrick D, et al. Assessment of health-related quality of life in patients with interstitial lung disease. Chest 1999; 116: 1175-1182.

112 Bousquet J, Knani J, Dhivert H, et al. Quality of life in asthma. Internal consistency and validity of the SF-36 questionnaire. Am J Respir Crit Care Med 1994; 149: 371-375.

113 Williams J, Singh S, Sewell L, et al. Development of a self-reported Chronic Respiratory Questionnaire (CRQ-SR). Thorax 2001; 56: 954-959.

114 Guyatt G, Berman L, Townsend M, et al. A measure of quality of life for clinical trials in chronic lung disease. Thorax 1987; 42: 773-778.

115 Vodanovich D, Bicknell T, Holland A, et al. Validity and reliability of the Chronic Respiratory Disease Questionnaire in elderly individuals with mild to moderate non-cystic fibrosis bronchiectasis. Respiration 2014; 90: 89-96

116 Jones P, Harding G, Berry P, et al. Development and first validation of the COPD Assessment Test. Eur Respir J 2009; 34: 648-654.

117 Lanza F, Castro R, de Carmargo A, et al. COPD Assessment Test (CAT) is a valid and simple tool to measure the impact of bronchiectasis on affected patients. COPD 2018; 15: 512-519.

118 Murray M, Turnbull K, MacQuarrie S, et al. Validation of the Leicester Cough Questionnaire in non-cystic fibrosis bronchiectasis. Eur Respir J 2009; 34: 125-131.

119 Fletcher C, Elmes P, Fairbain A, et al. The significance of respiratory symptoms and the diagnosis of chronic bronchitis in a working population. Br Med J 1959; 2: 257-266.

120 Bestall J, Paul E, Garrod R, et al. Usefulness of the Medical Research Council (MRC) dyspnoea scale as a measure of disability in patients with chronic obstructive pulmonary disease. Thorax 1999; 54: 581-586.

121 Yorke J, Russell A, Swigris J, et al. Assessment of dyspnoea in asthma: validation of the Dyspnoea-12. J Asthma 2011; 48: 602-608.

122 Manali E, Lyberopoulos P, Triantafillidou C. MRC chronic Dyspnea Scale: relationships with cardiopulmonary exercise testing and 6-minute walk test in idiopathic pulmonary fibrosis patients: a prospective study. BMC Pul Med 2010; 10: 32

123 Williams N. The MRC breathlessness scale. Occup Med 2017; 67: 496-497.

124 Prasad S, Randall S, Balfour-Lynn M. Fifteen-count breathlessness score: an objective measure for children. Paediatr Pulmonol 2000; 30: 56-62.

125 Borg G. Perceived exertion as an indicator of somatic stress. Scand J Rehab Med 1970; 2: 92-98.

126 Burdon J, Juniper E, Killian K, et al. The perception of breathlessness in asthma. Am Rev Respir Dis 1982; 126: 825-828.

127 Herrero Cortina B, Aliberti S, Blasi F, et al. Chest physiotherapy in European patients with bronchiectasis: data from the EMBARC registry. Eur Respir J 2017: 50: Suppl. 61, PA4071.

128 McCullough A, Tunney M, Elborn J, et al. Predictors on adherence in bronchiectasis. Respir Med 2015; 109: $838-845$.

129 McCullough A, Tunney M, Elborn J, et al. 'All illness is personal to that individual': a qualitative study of patients' perspectives on treatment adherence in bronchiectasis. Health Expect 2015; 18: 2477-2488.

130 McCullough A, Tunney M, Quittner A, et al. Treatment adherence and health outcomes in patients with bronchiectasis. BMC Pulm Med 2014; 14: 107.

131 Spinou A, Lee K, Sinha A, et al. The objective assessment of cough frequency in bronchiectasis. Lung 2017; 195: $575-585$.

132 Martinez-Garcia M, Maiz L, Olveira C, et al. Spanish guidelines on treatment of bronchiectasis in adults. Arch Bronconeumol 2018; 54: 88-98.

133 Spinou A, Chalmers J. Respiratory physiotherapy in the bronchiectasis guidelines: is there a loud voice we are yet to hear? Eur Respir J 2019; 54: 1901610.

134 Lavery K, O’Neill B, Elborn J, et al. Self-management in bronchiectasis: the patients' perspective. Eur Respir J 2007; 29: 541-547.

135 Hall K, Kuys S, Masel P, et al. Outpatient physiotherapy improves quality of life for non-CF bronchiectasis. Respirology 2014; 19: 96. 